\title{
Fabrication of solid and hollow carbonate apatite microspheres as bone substitutes using calcite microspheres as a precursor
}

\author{
Kazuhiro SUNOUCHI ${ }^{1,2}$, Kanji TSURU ${ }^{1}$, Michito MARUTA ${ }^{3}$, Giichiro KAWACHI ${ }^{1}$, Shigeki MATSUYA ${ }^{3}$, \\ Yoshihiro TERADA ${ }^{2}$ and Kunio ISHIKAWA ${ }^{1}$ \\ ${ }^{1}$ Department of Biomaterials, Faculty of Dental Science, Kyushu University, 3-1-1 Maidashi, Higashi-ku, Fukuoka 812-8582, Japan \\ ${ }^{2}$ Department of Fixed Prosthodontics, Faculty of Dental Science, Kyushu University, 3-1-1 Maidashi, Higashi-ku, Fukuoka 812-8582, Japan \\ ${ }^{3}$ Section of Bioengineering, Fukuoka Dental College, 2-15-1 Tamura, Sawara-ku, Fukuoka 814-0193, Japan \\ Corresponding author, Kanji TSURU; E-mail: tsuru@dent.kyushu-u.ac.jp
}

Spherical carbonate apatite $\left(\mathrm{CO}_{3} \mathrm{Ap}\right)$ microspheres approximately $1 \mathrm{~mm}$ in diameter were fabricated by granulation of calcium hydroxide around a core followed by carbonation and phosphatization through dissolution-precipitation reaction. $\mathrm{CO}_{3} \mathrm{Ap}$ microspheres with high uniformity could not be achieved without using a core. Solid $\mathrm{CO}_{3} \mathrm{Ap}$ microspheres were obtained using a calcite core whereas hollow $\mathrm{CO}_{3} \mathrm{Ap}$ microspheres were obtained using a $\mathrm{NaCl}$ core. The obtained microsphere was identified as $\mathrm{B}$-type $\mathrm{CO}_{3} \mathrm{Ap}$ by Fourier transform infrared analysis and the carbonate content was approximately $7-8 \mathrm{wt} \%$ regardless of the type of core used for sample preparation. The mechanical strength of both the solid and hollow $\mathrm{CO}_{3} \mathrm{Ap}$ microspheres was sufficient for practical use as a bone substitute.

Keywords: Carbonate apatite, Microsphere, Hollow, Bone substitute

\section{INTRODUCTION}

As bone substitutes, hydroxyapatite $\left(\mathrm{HAp}^{\mathrm{Ca}} \mathrm{Ca}_{10}\left(\mathrm{PO}_{4}\right)_{6}(\mathrm{OH})_{2}\right)$ and $\beta$-tricalcium phosphate ( $\beta$-TCP: $\left.\beta-\mathrm{Ca}_{3}\left(\mathrm{PO}_{4}\right)_{2}\right)$ are popular for clinical use and both show excellent osteoconductivity. However, HAp is not completely resorbed by the osteoclasts in the remodeling cycle of the osseous tissue because HAp is too stable and has extremely low solubility. On the other hand, the resorption process of $\beta$-TCP is a physicochemical dissolution, and it is reported that though $\beta$-TCP was successfully replaced by new bone at an active site of bone formation, it sometimes gave a poor prognosis at a less active site. The inorganic phase of bone composition has been idealized as $\mathrm{HAp}^{1)}$, but studies on both synthetic and biological apatites demonstrated that the bone mineral was a carbonate apatite $\left(\mathrm{CO}_{3} \mathrm{Ap}\right)$ represented by a generalized chemical formula, $\mathrm{Ca}_{10-\mathrm{a}}\left(\mathrm{PO}_{4}\right)_{6-\mathrm{b}}\left(\mathrm{CO}_{3}\right)_{\mathrm{b}}(\mathrm{OH})_{2-\mathrm{c} \text {. }} \quad \mathrm{CO}_{3}{ }^{2-}$ ion substitutes $\mathrm{PO}_{4}{ }^{3-}$ or $\mathrm{OH}^{-}$ion. The $\mathrm{Ca}^{2+}$ ion could also be substituted by various ions such as $\mathrm{Mg}^{2+}, \mathrm{Na}^{+}$or $\mathrm{Sr}^{2+}$, and the $\mathrm{OH}^{-}$ ion by $\mathrm{F}^{-}$or $\mathrm{Cl}^{-}$ion ${ }^{2,3)}$. The substituted amounts of a, $\mathrm{b}$ and $\mathrm{c}$ varied to keep the electroneutrality of $\mathrm{CO}_{3} \mathrm{Ap}$. In the remodeling process of bone, osteoclasts produced a weak acidic environment of $\mathrm{pH} 3-5$ in Howship's lacuna to dissolve the bone minerals. LeGeros and Ming reported the relationship between carbonate content in apatitic structure and solubility of apatite under weak acidic conditions ${ }^{4}$. The solubility of apatite increases with an increase in the carbonate content of apatite. This result indicates clearly that the carbonate content in apatitic structure plays a dominant role for in the dissolution of apatite. In other words, $\mathrm{CO}_{3} \mathrm{Ap}$ is soluble in Howship's lacuna whereas HAp is not soluble. Therefore, $\mathrm{CO}_{3} \mathrm{Ap}$ is a key factor if it is desired that the artificial bone substitute will be replaced by new bone based on the bone remodeling process. Thus, $\mathrm{CO}_{3} \mathrm{Ap}$ would be a better candidate as a bone substitute biomaterial. It is ideal for a bone substitute to have a similar structure as well as properties to bone ${ }^{5}$. Bone has a fully interconnected pore structure that allows the tissue ingrowth and nourishment of bone cells necessary for optimum bone growth or repair ${ }^{5,6}$. Therefore, we have attempted to fabricate a calcium phosphate bone substitute with a fully-interconnected porous structure for a decade. Wakae et al. reported that a $\mathrm{CO}_{3} \mathrm{Ap}$ foam with interconnected porous structure could be fabricated by hydrothermal treatment of $\alpha$-tricalcium phosphate $\left(\alpha-\mathrm{TCP}: \alpha-\mathrm{Ca}_{3} \mathrm{PO}_{4}\right)$ foam in the presence of ammonium carbonate $\left(\left(\mathrm{NH}_{4}\right)_{2} \mathrm{CO}_{3}\right)$ solution at $200^{\circ} \mathrm{C}$ for $24 \mathrm{~h}^{7}$. However, this $\mathrm{CO}_{3} \mathrm{Ap}$ foam was very weak in mechanical strength and did not have the molding ability to obtain the desired shape. Later Karashima et al. reported that porous HAp blocks with molding ability could be obtained by the setting reaction of $\alpha$-TCP foam granules ${ }^{8}$. In short, $\alpha$-TCP foam was crushed into granules which had an interconnected porous structure, and the resulting granules were treated under hydrothermal condition with distilled water at $200^{\circ} \mathrm{C}$ for $24 \mathrm{~h}$. However, the hydrothermal treatment resulted in HAp with high crystallinity and slower resorption rate. HAp with low crystallinity exhibited higher resorption rate and better bioactivity in bone graft space ${ }^{9)}$. On the other hand, it was reported that closed-packing of microspheres of 1 $\mathrm{mm}$ in diameter gave 3-dimensionally interconnected pores of 200-500 $\mu \mathrm{m}$ in size, ideal for ingrowth of blood vessels and new bone tissue ${ }^{10-13)}$. If we could prepare microspheres made of $\mathrm{CO}_{3} \mathrm{Ap}$, they are expected to be a good candidate for a bone substitute with excellent resorbability. Several researchers ${ }^{14,15}$ have reported on 
preparation of spherical HAp or $\mathrm{CO}_{3} \mathrm{Ap}$ with diameter of a few $\mu \mathrm{m}$ to $1 \mathrm{~mm}$; however, there seems to be no report on spherical $\mathrm{CO}_{3} \mathrm{Ap}$ of $1 \mathrm{~mm}$ diameter at present. Some preparation methods for ceramics granules with large size (more than $1 \mathrm{~mm}$ in diameter) were reported such as compaction/granulation ${ }^{16)}$, tumbling granulation $^{17)}$, agitation fluidized-bed granulation ${ }^{18)}$ and other methods ${ }^{19)}$. Among them, tumbling granulation is a suitable for our purpose since large size ceramic microsphere can be prepared with high productivity and without valuable equipment.

Though solid $\mathrm{CO}_{3} \mathrm{Ap}$ microspheres can build up a 3-dimensional porous structure, if there was a hollow space inside the microsphere, the hollow space would allow effective permeation of blood and cells, and enable easier $\mathrm{CO}_{3} \mathrm{Ap}$ resorption. Moreover, hollowtype HAp microspheres have received much attention as a controlled drug-delivery device of drugs or growth factors ${ }^{20-22)}$. Thus a $\mathrm{CO}_{3} \mathrm{Ap}$ microsphere with a hollow space is also expected to be a good candidate for a bone substitute with rapid bone formation.

In this study, the authors established a new fabrication method of both $\mathrm{CO}_{3} \mathrm{Ap}$ solid and hollow microspheres of about $1 \mathrm{~mm}$ in diameter, and their physicochemical properties were investigated.

\section{MATERIALS AND METHODS}

\section{Preparation of core}

Two kinds of cores, that is, calcium hydroxide $\left(\mathrm{Ca}(\mathrm{OH})_{2}\right)$, and calcium carbonate $\left(\mathrm{CaCO}_{3}\right.$ : calcite) were used for fabrication of a solid-type $\mathrm{CO}_{3} \mathrm{Ap}$ microsphere, while sodium chloride $(\mathrm{NaCl})$ was used for a hollow-type $\mathrm{CO}_{3} \mathrm{Ap}$ microsphere. $0.2 \mathrm{~g}$ of $\mathrm{Ca}(\mathrm{OH})_{2}$ powder (Wako Chemical
Co. Ltd., Osaka, Japan) was placed in a stainless steel mold with inner diameter of $6 \mathrm{~mm}$ and pressed uniaxially under $100 \mathrm{MPa}$ pressure. The $\mathrm{Ca}(\mathrm{OH})_{2}$ compact green block was crushed with a hammer and sieved to collect particles between 300 and $500 \mu \mathrm{m}$ in size, these were used as the $\mathrm{Ca}(\mathrm{OH})_{2}$ core. The $\mathrm{Ca}(\mathrm{OH})_{2}$ compact was also treated in a stream of $\mathrm{CO}_{2}$ gas saturated with water vapor at room temperature for 2 weeks to convert it into calcite ${ }^{23,24)}$. The obtained calcite blocks were crushed with a hammer and sieved to collect particles between 300 and $500 \mu \mathrm{m}$ in size, these were used as the calcite core. For fabrication of hollow-type $\mathrm{CO}_{3} \mathrm{Ap}$, water-soluble $\mathrm{NaCl}$ was used as the core material. A commercially available $\mathrm{NaCl}$ (Wako Chemical Co. Ltd.) was sieved to collect particles between 300 and $500 \mu \mathrm{m}$ in size and these were used as the $\mathrm{NaCl}$ core.

\section{Preparation of $\mathrm{CO}_{3} \mathrm{Ap}$ microsphere}

Each core was put into a rotary granulator (angle of inclination $40^{\circ}$ ), turned at a rotating speed of $40 \mathrm{rpm}$ and misted with a small amount of water by atomist spray to wet the core surface. Then an appropriate amount $\mathrm{Ca}(\mathrm{OH})_{2}$ powder was added and the core was granulated. This procedure was repeated several times until the granule size attained approximately $1 \mathrm{~mm}$ in diameter. The $\mathrm{Ca}(\mathrm{OH})_{2}$ precursor microsphere with a different core, $\mathrm{Ca}(\mathrm{OH})_{2}$, calcite or $\mathrm{NaCl}$ was treated again in a stream of $100 \% \mathrm{CO}_{2}$ gas saturated with water vapor at room temperature for two weeks to convert it into calcite ${ }^{23,24)}$ and was used as a precursor. The calcite microsphere with the core was transformed into $\mathrm{CO}_{3} \mathrm{Ap}$ in $1 \mathrm{~mol} / \mathrm{L} \mathrm{Na}_{2} \mathrm{HPO}_{4}$ solution at $60^{\circ} \mathrm{C}$ for 2 weeks ${ }^{25}$. Figure 1 shows a schematic representation of the preparation method of solid and hollow $\mathrm{CO}_{3} \mathrm{Ap}$ microspheres.

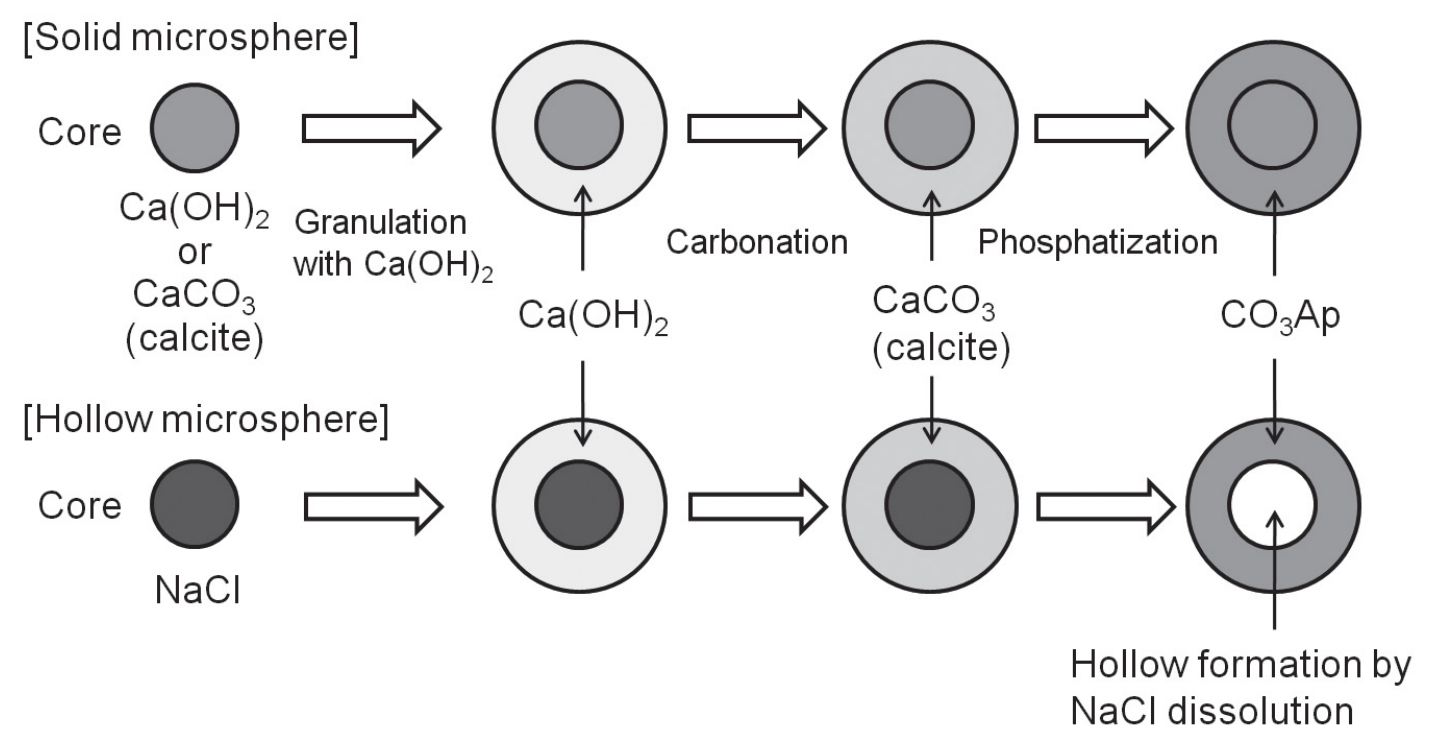

Fig. 1 A schematic representation of the preparation method of solid and hollow $\mathrm{CO}_{3} \mathrm{Ap}$ microspheres. 
Characterization of the precursor and $\mathrm{CO}_{3} \mathrm{Ap}$ microsphere Sphericity of the precursor and $\mathrm{CO}_{3} \mathrm{Ap}$ microsphere was evaluated according to the following equation (1).

$$
\text { Sphericity }=L_{\max } / L_{\min }
$$

where $L_{\max }$ means the maximum diameter of the microsphere and $L_{\min }$ means the minimum diameter.

If the microsphere was a true sphere, sphericity would be 1 . The composition of the precursors and $\mathrm{CO}_{3} \mathrm{Ap}$ microspheres was evaluated by means of powder X-ray diffraction (XRD). The specimens were ground into fine powder for the XRD analysis. Diffraction patterns of the specimens were recorded with a vertically mounted diffractometer system (D8 ADVANCE, Bruker AXS Co. Ltd., Karlsruhe, Germany) using Ni filtered CuKa radiation generated at $40 \mathrm{kV}$ and $40 \mathrm{~mA}$. Specimens were scanned from $20^{\circ}$ to $40^{\circ}$ of $2 \theta$ (where $\theta$ is the Bragg angle) in a continuous mode, and references for $\mathrm{HAp}$ and $\mathrm{CaCO}_{3}$ and $\mathrm{Ca}(\mathrm{OH})_{2}$ identifications were obtained from JCPDS cards. Fourier transform infrared (FT-IR) analysis of the $\mathrm{CO}_{3} \mathrm{Ap}$ microsphere was also carried out using the $\mathrm{KBr}$ method with a FT-IR spectrometer (Spectrum 2000LX; Perkin-Elmer Co. Ltd., Massachusetts, USA). Quantitative analysis of the carbonate content in the $\mathrm{CO}_{3} \mathrm{Ap}$ microsphere was performed using a $\mathrm{CHN}$ coder (CHN coder-MT-6, Yonako Analytical Instruments Corp., Kyoto, Japan). The apparent density of the $\mathrm{CO}_{3} \mathrm{Ap}$ microsphere was obtained by dividing its weight by its volume and porosity was calculated by the following equation (2),

Porosity of $\mathrm{CO}_{3} \mathrm{Ap}$ microsphere

$=100 \times\left(d_{\mathrm{CO}_{3} \mathrm{Ap}}-d_{\mathrm{CO}_{3} \mathrm{Ap} \text { microsphere }}\right) / d_{\mathrm{CO}_{3} \mathrm{Ap}}$

where $d_{\mathrm{CO}_{3} \mathrm{Ap} \text { microsphere }}$ and $d_{\mathrm{CO}_{3} \mathrm{Ap}}$ are the apparent density of a $\mathrm{CO}_{3} \mathrm{Ap}$ microsphere and the theoretical density of $\mathrm{CO}_{3} \mathrm{Ap}$. The mechanical strength of the $\mathrm{CO}_{3} \mathrm{Ap}$ microsphere was evaluated in uniaxial compression mode using a universal testing machine (AGS-J, Shimadzu Co., Kyoto, Japan) at a crosshead speed of $1 \mathrm{~mm} / \mathrm{min}$. The mechanical strength was obtained as a maximum load at fracture of the microsphere and the strength value was taken as the average of at least ten specimens. Surface and cross-sectional structures of the $\mathrm{CO}_{3} \mathrm{Ap}$ microsphere were observed using scanning electron microscope (SEM) (S3400N, Hitachi High Technologies Co. Ltd., Tokyo, Japan) after sputter-coating with gold.

\section{RESULTS}

Figure 2 shows photographs of the precursors with various cores. When no core was used for granulation, the precursor showed an oval-like spherical shape and the particle were not uniform. However, the shape of the granule became more spherical when a core was used. Calcite and $\mathrm{NaCl}$ cores gave an almost spherical and homogeneous granule size. Table 1 shows the sphericity of the precursor microspheres when granulated with no core, $\mathrm{Ca}(\mathrm{OH})_{2}$ core, calcite core and $\mathrm{NaCl}$ core. Though
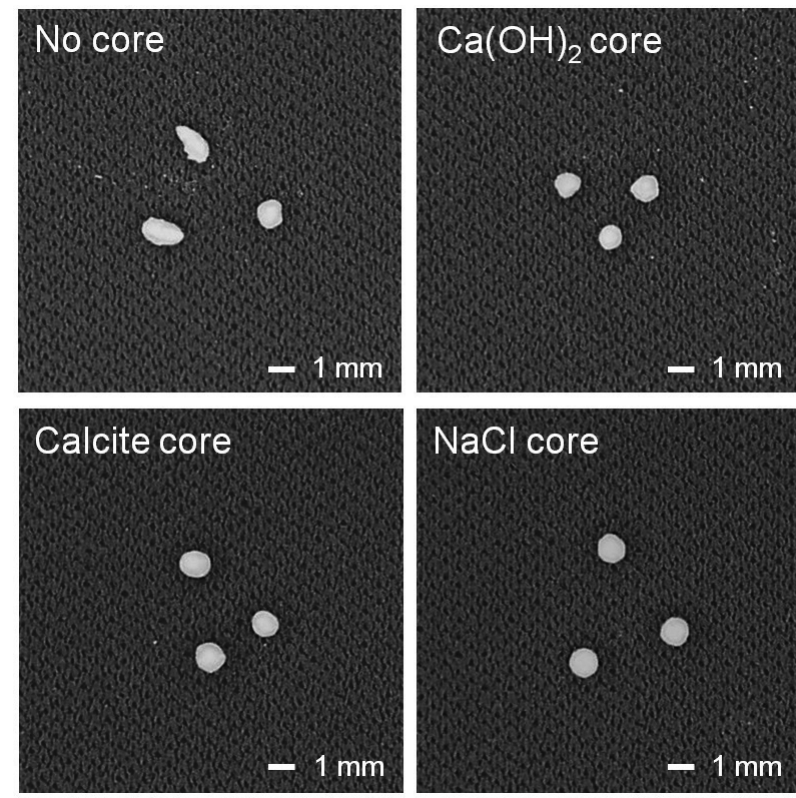

Fig. 2 Photographs of the precursor microspheres with various cores.

Table 1 Sphericity with no core, $\mathrm{Ca}(\mathrm{OH})_{2}$ core, $\mathrm{CaCO}_{3}$ core and $\mathrm{NaCl}$ core

\begin{tabular}{cc}
\hline Sample name & Sphericity \\
\hline No core & $1.18 \pm 0.29$ \\
$\mathrm{Ca}(\mathrm{OH})_{2}$ & $1.12 \pm 0.22$ \\
$\mathrm{Calcite}$ & $1.06 \pm 0.08$ \\
$\mathrm{NaCl}$ & $1.03 \pm 0.14$ \\
\hline
\end{tabular}

sphericity was between 1.18 and 1.02 depending on the core materials, there are no significant differences between the values. However, the microspheres with a calcite core and $\mathrm{NaCl}$ core seemed to show high sphericity, so these were used for our experiment.

Figure 3 shows the XRD patterns of $\mathrm{Ca}(\mathrm{OH})_{2}$ granules with calcite and $\mathrm{NaCl}$ cores before and after carbonation in a water-saturated $\mathrm{CO}_{2}$ stream at room temperature for 1 day, 3 days, 7 days, and 14 days. Figure 4 shows the conversion ratio of $\mathrm{Ca}(\mathrm{OH})_{2}$ to calcite with time for granules with calcite and $\mathrm{NaCl}$ cores. In both of the $\mathrm{Ca}(\mathrm{OH})_{2}$ granules with calcite and $\mathrm{NaCl}$ cores, 70-80 mass\% of calcite was formed after carbonation for 1 day. Carbonation occurred gradually from then and the rest of the $\mathrm{Ca}(\mathrm{OH})_{2}$ was fully converted into calcite after carbonation for 14 days.

Figure 5 shows the XRD patterns of calcite microspheres with calcite and $\mathrm{NaCl}$ cores phosphatized in $1 \mathrm{~mol} / \mathrm{L} \mathrm{Na}_{2} \mathrm{HPO}_{4}$ solution at $60^{\circ} \mathrm{C}$ up to 14 days. 

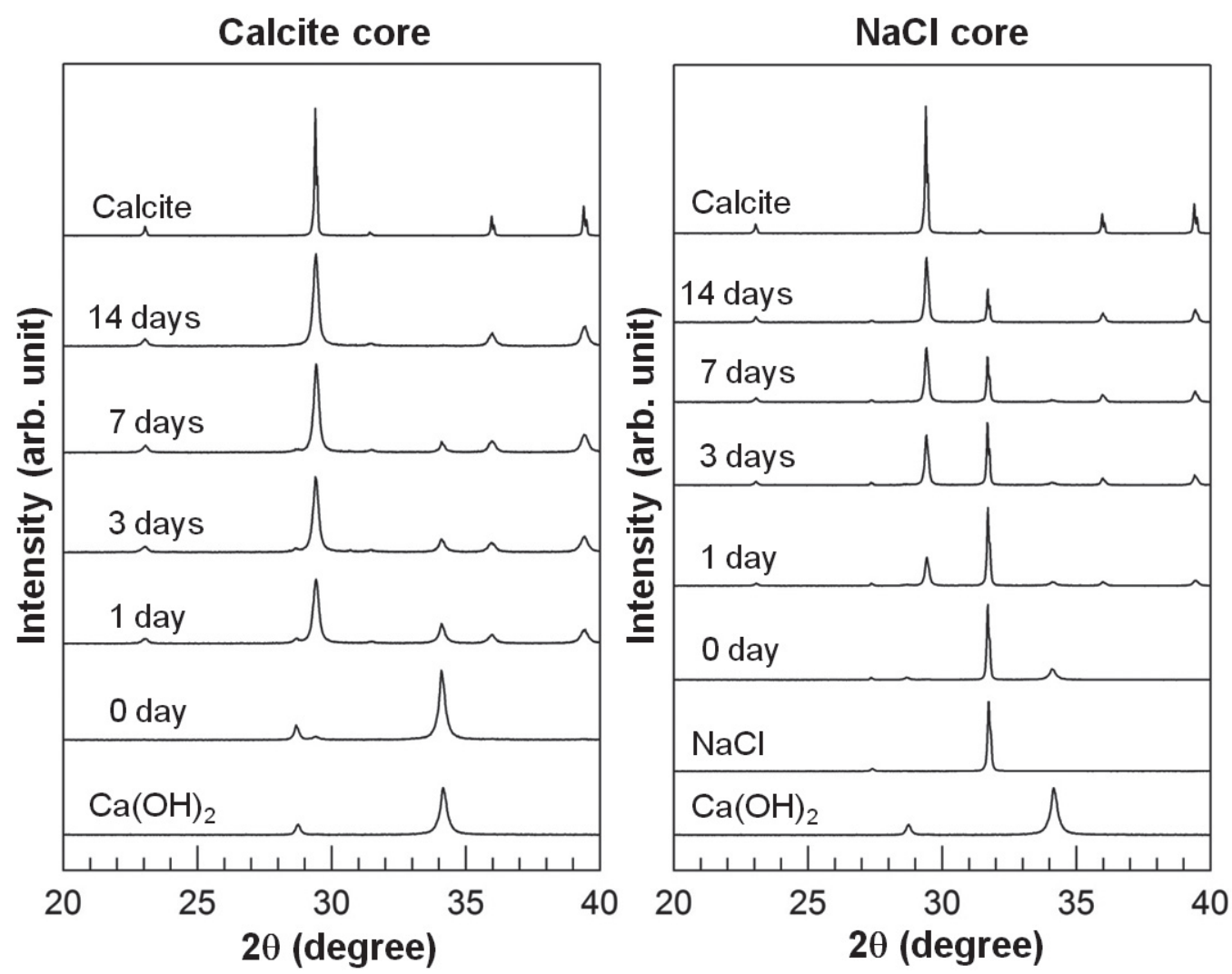

Fig. 3 XRD patterns of $\mathrm{Ca}(\mathrm{OH})_{2}$ microsphere prepared using calcite core (left) and $\mathrm{NaCl}$ core (right) before and after carbonation for different periods. $\mathrm{Ca}(\mathrm{OH})_{2}, \mathrm{NaCl}$ and calcite are also included for comparison.

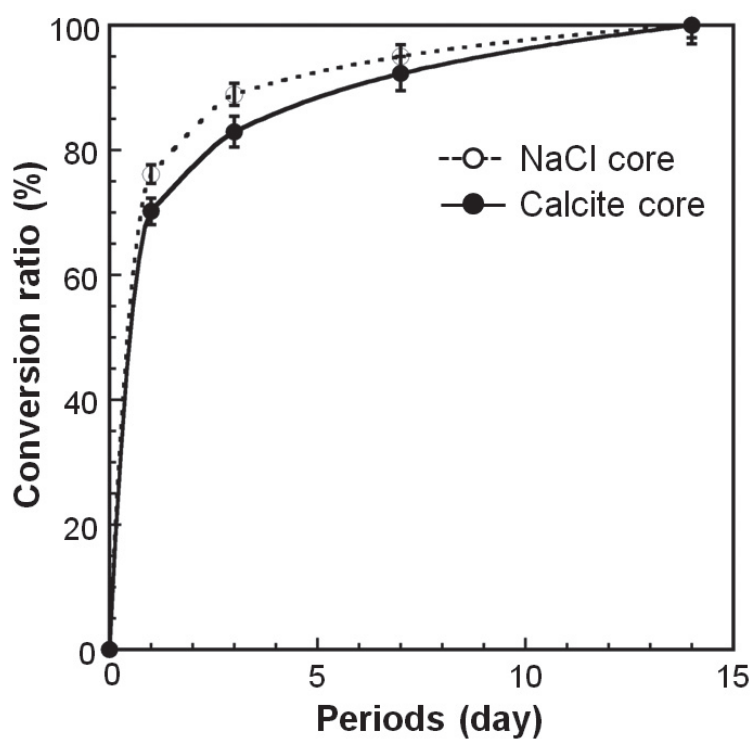

Fig. 4 Change in conversion ratio of $\mathrm{Ca}(\mathrm{OH})_{2}$ microsphere to calcite microsphere with time during carbonation.
Figure 6 shows the conversion ratio of calcite into $\mathrm{CO}_{3} \mathrm{Ap}$ with time. For the calcite granules with a calcite core, most of the calcite was converted into apatite phase (about 85 mass\%) after phosphatization for 1 day. Phosphatization occurred gradually from then, as in carbonation, and only a small amount of calcite remained even after phosphatization for 14 days. It may be difficult for the calcite core to convert into apatite phase because it has a higher density than the outer shell. For the calcite granules with a $\mathrm{NaCl}$ core, though similar conversion of calcite into apatite phase occurred, the $\mathrm{NaCl}$ core was completely absent after 1 day. This means that the $\mathrm{NaCl}$ core completely dissolved out during phosphatization, and left a hollow space inside the microsphere. Formation of the hollow space was confirmed by SEM observation described later.

Figure 7 shows the FT-IR spectra of the calcite microspheres with calcite (solid) and $\mathrm{NaCl}$ (hollow) cores phosphatized in $1 \mathrm{~mol} / \mathrm{L} \mathrm{Na}_{2} \mathrm{HPO}_{4}$ solution at $60^{\circ} \mathrm{C}$ for 14 days. The FT-IR spectrum of HAp is also shown as a reference. The spectra for both the solid- and hollowtype $\mathrm{CO}_{3} \mathrm{Ap}$ microspheres show several absorption bands due to $\mathrm{PO}_{4}$ group at $1200-900 \mathrm{~cm}^{-1}$ and $650-500$ $\mathrm{cm}^{-1}$, and $\mathrm{CO}_{3}$ group at $1550-1350 \mathrm{~cm}^{-1}$ and at about 870 $\mathrm{cm}^{-1}$. The absorption bands for $\mathrm{PO}_{4}$ group corresponded 

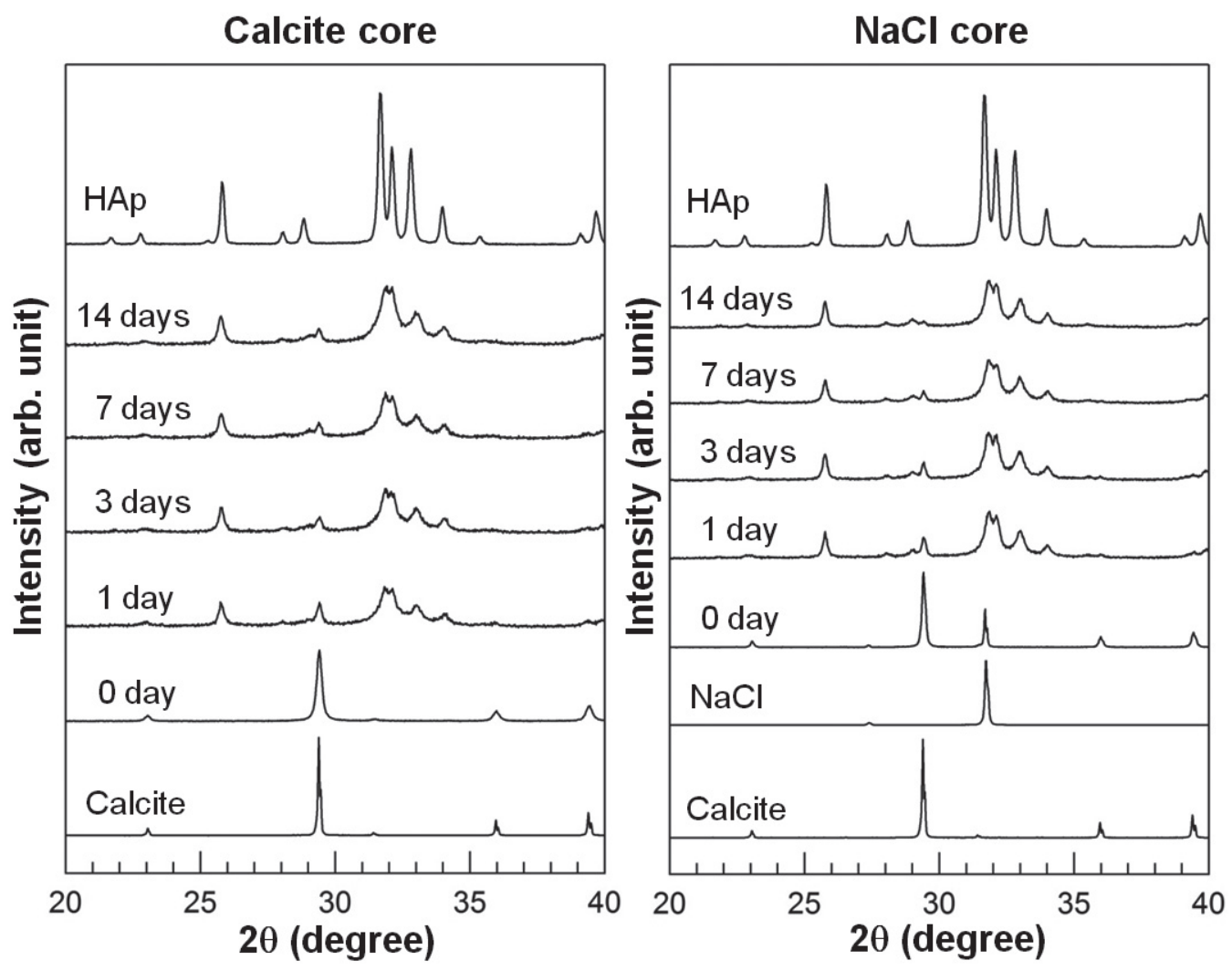

Fig. 5 XRD patterns of calcite microsphere prepared using calcite core (left) and NaCl core (right) before and after phosphataization for different periods. Calcite, $\mathrm{NaCl}$ and $\mathrm{HAp}$ are also included for comparison.

to those for HAp. The absorption band for $\mathrm{CO}_{3}$ clearly shows that carbonate ions, $\mathrm{CO}_{3}{ }^{2-}$ are involved in the apatite lattice, because the XRD patterns only showed formation of the apatite phase.

Figure 8 shows the SEM photographs of the solid (a) and hollow $\mathrm{CO}_{3} \mathrm{Ap}$ microsphere (b) at low and high magnification. As shown in these photographs, granular $\mathrm{CO}_{3} \mathrm{Ap}$ crystals were seen on the surfaces of the microspheres, and the apparent crystal size seemed to be slightly smaller in the solid $\mathrm{CO}_{3} \mathrm{Ap}$ microspheres. Figure 9 shows the SEM photographs of cross-sections of the solid (a) and hollow $\mathrm{CO}_{3} \mathrm{Ap}$ microspheres (b) at low and high magnification. The bright section in the central part of solid microsphere showed the calcite core in intimate contact with the shell. However, the surrounding $\mathrm{CO}_{3} \mathrm{Ap}$ crystals seemed to be loosely packed towards the outer surface. With the hollow $\mathrm{CO}_{3} \mathrm{Ap}$ microsphere, a hollow space was clearly seen in the center part of the microsphere indicating the $\mathrm{NaCl}$ core had dissolved out. The hollow-type $\mathrm{CO}_{3} \mathrm{Ap}$ microsphere showed a more closely packed structure than the solidtype one.

Table 2 summarizes the physicochemical properties, such as carbonate content, apparent porosity and compressive strength for the solid- and hollow-type

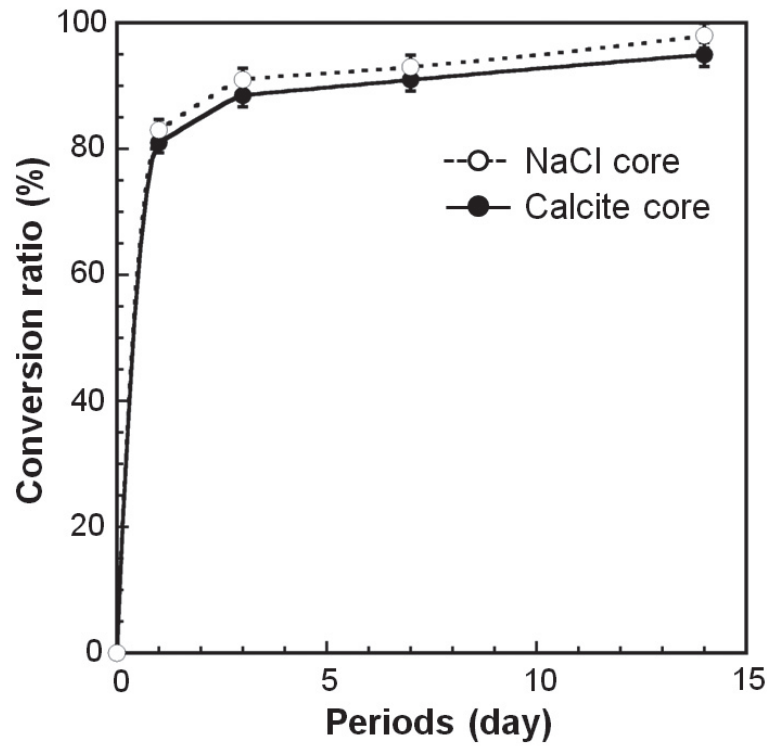

Fig. 6 Change in conversion ratio of calcite microsphere to with $\mathrm{CO}_{3} \mathrm{Ap}$ microsphere with time during phosphatization. 


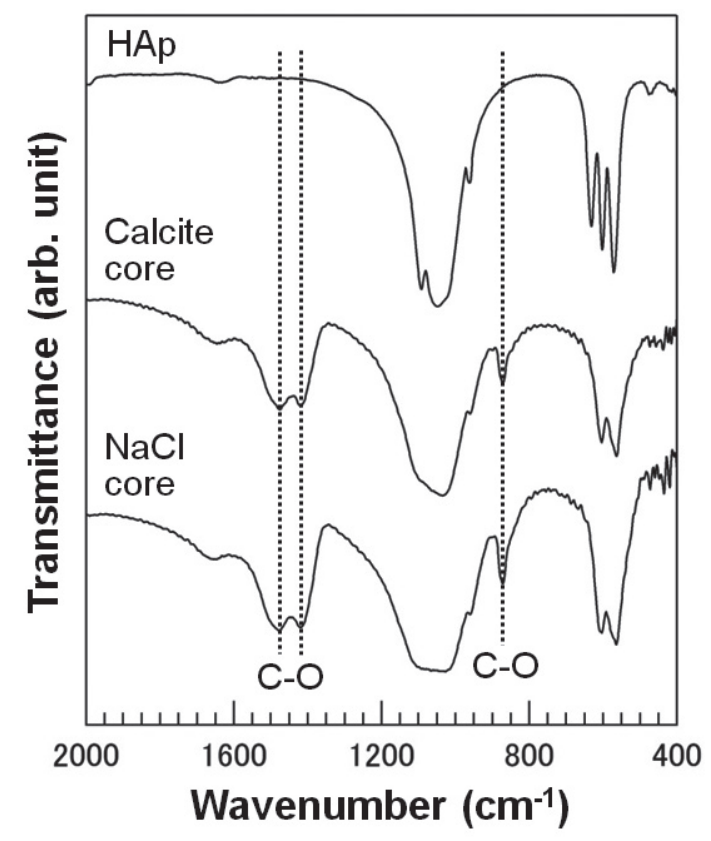

Fig. 7 FT-IR spectra of $\mathrm{CO}_{3} \mathrm{Ap}$ microspheres prepared using calcite core and $\mathrm{NaCl}$ core.
$\mathrm{CO}_{3} \mathrm{Ap}$ microspheres. Carbonate content is 7.9 mass $\%$ in the solid microsphere, and 8.4 mass\% in the hollowtype microsphere, which is very close to the average carbonate content of 7.4 mass\% in human bone. The apparent density of the solid microsphere was 1.60 $\mathrm{g} / \mathrm{cm}^{3}(n=30)$ and the resultant porosity was $48.1 \mathrm{vol} \%$. On the other hand, the apparent density of the hollow microsphere was $1.07 \mathrm{~g} / \mathrm{cm}^{3}(n=30)$ and the porosity was $65.2 \mathrm{vol} \%$. The compressive strength of the microspheres was $1.4 \pm 0.4 \mathrm{~N}$ for the solid-type and $1.9 \pm 0.3 \mathrm{~N}$ for the hollow-type. Unexpectedly, the hollow-type showed higher strength than the solid-type.

\section{DISCUSSION}

The present study clearly demonstrated that solid and hollow $\mathrm{CO}_{3} \mathrm{Ap}$ microspheres could be successfully prepared using a novel method to fabricate $\mathrm{CO}_{3} \mathrm{Ap}$ based on dissolution-precipitation reaction. When microspheres of $1 \mathrm{~mm}$ in diameter were close-packed, for example, a 3-dimensional porous structure with pores of approximately $500 \mu \mathrm{m}$ in size would be constructed ${ }^{25)}$. It was reported that interconnected pores with $300-500$ $\mu \mathrm{m}$ in diameter are enough large for bone cells such

\section{Calcite core}

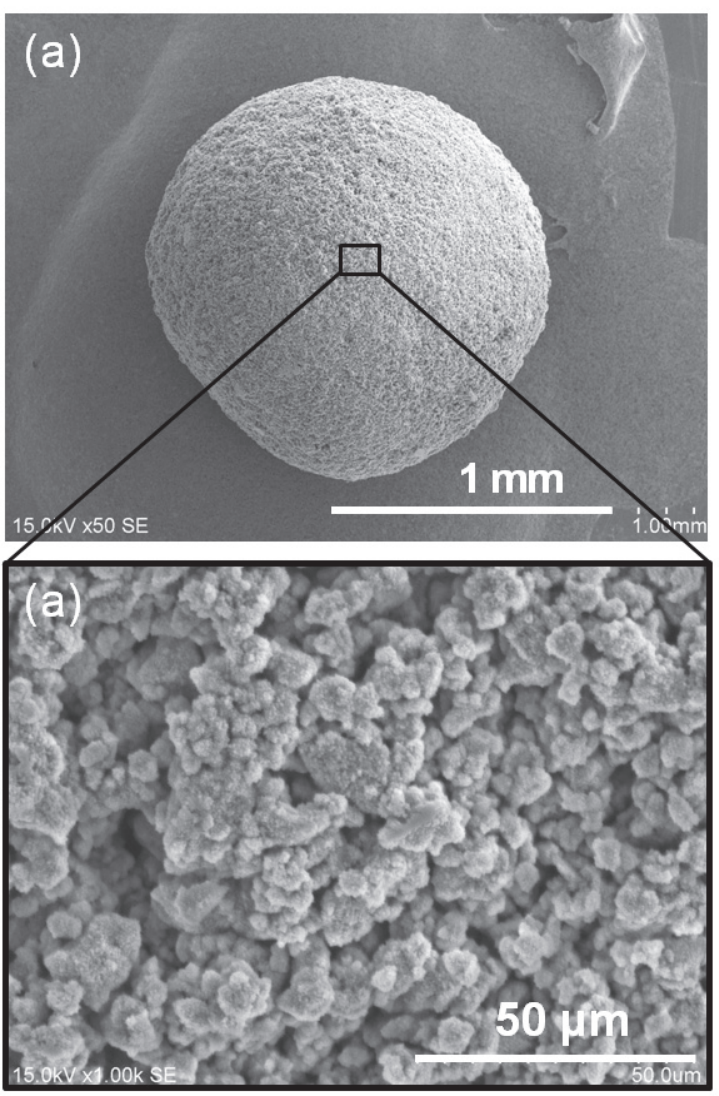

$\mathrm{NaCl}$ core

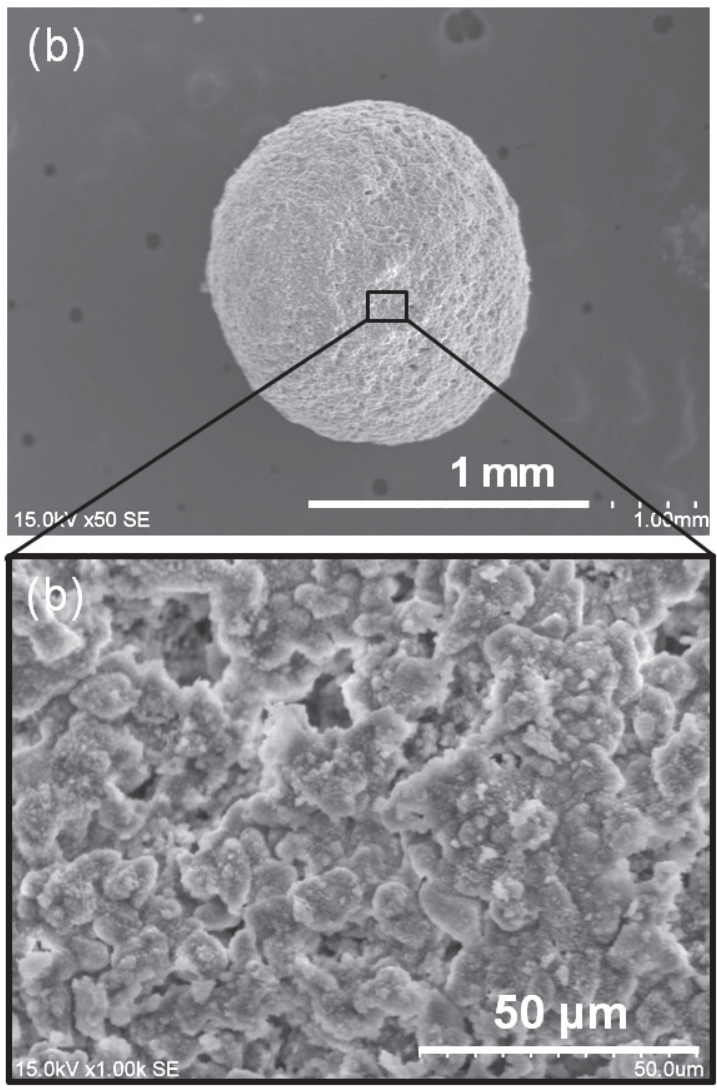

Fig. 8 Surface SEM images for $\mathrm{CO}_{3} \mathrm{Ap}$ microsphere prepared using calcite core (a) and $\mathrm{NaCl}$ core (b). 
as osteoblasts ${ }^{13-16)}$ to penetrate into the pores. A pore size of $500 \mu \mathrm{m}$ seems to be ideal for cell penetration and cell revascularization. Therefore, fabrication of a microsphere with $1 \mathrm{~mm}$ diameter makes it easy to construct a 3-dimensional porous structure with pores of approximately $500 \mu \mathrm{m}$ in size. For spherical granulation, selection of the core material is especially important to control the sphericity of the obtained microsphere. As shown in the present study, for the tumbling granulation method with no core, the granule size was not homogenous and its shape was not spherical, but oval-like. Moreover, its strength was too low and it was easily broken. When a core was used for the tumbling granulation, more spherical microspheres were obtained. As shown in Table 1, sphericity of the precursors was closer to 1 . Although there was no statistically significant difference in sphericity between microspheres with different cores, decreasing order of each standard deviation becomes no core $>\mathrm{Ca}(\mathrm{OH})_{2}$ core $>\mathrm{NaCl}$ core $>$ calcite core. This result indicates that the sphericity of microsphere with no core is uneven when compared with that of microsphere with $\mathrm{NaCl}$ core or calcite core. Apparent density of the core was measured at $1.80 \mathrm{~g} / \mathrm{cm}^{3}$ for calcite and $2.13 \mathrm{~g} / \mathrm{cm}^{3}$ for $\mathrm{NaCl}$. Apparent density of $\mathrm{Ca}(\mathrm{OH})_{2}$ was lower than calcite. The order in apparent density of the core agreed well with that in uniformity of the resultant precursor microsphere. This indicates that the heavier core was more efficient for spherical granulation with uniform size. If the core is light in weight, it would easily bounce in the granulator and effective granulation would be difficult. On the other hand, a heavy core would granulate more effectively and densely. Thus, the $\mathrm{NaCl}$ and calcite cores with higher apparent densities gave microspheres with higher uniformity.

Apparent porosity of solid microsphere was approximately $48 \%$ due to inter granular space of

Table 2 Parameters of carbonate content, apparent porosity and compressive strength for solid and hollow carbonate apatite microspheres

\begin{tabular}{lcc}
\hline & Solid & Hollow \\
\hline Carbonate content (mass\%) & $7.9 \pm 1.5$ & $8.4 \pm 0.8$ \\
Apparent porosity (\%) & $48.1 \pm 1.4$ & $65.2 \pm 1.1$ \\
Compressive strength (N) & $1.4 \pm 0.4$ & $1.9 \pm 0.3$ \\
\hline
\end{tabular}

\section{Calcite core}
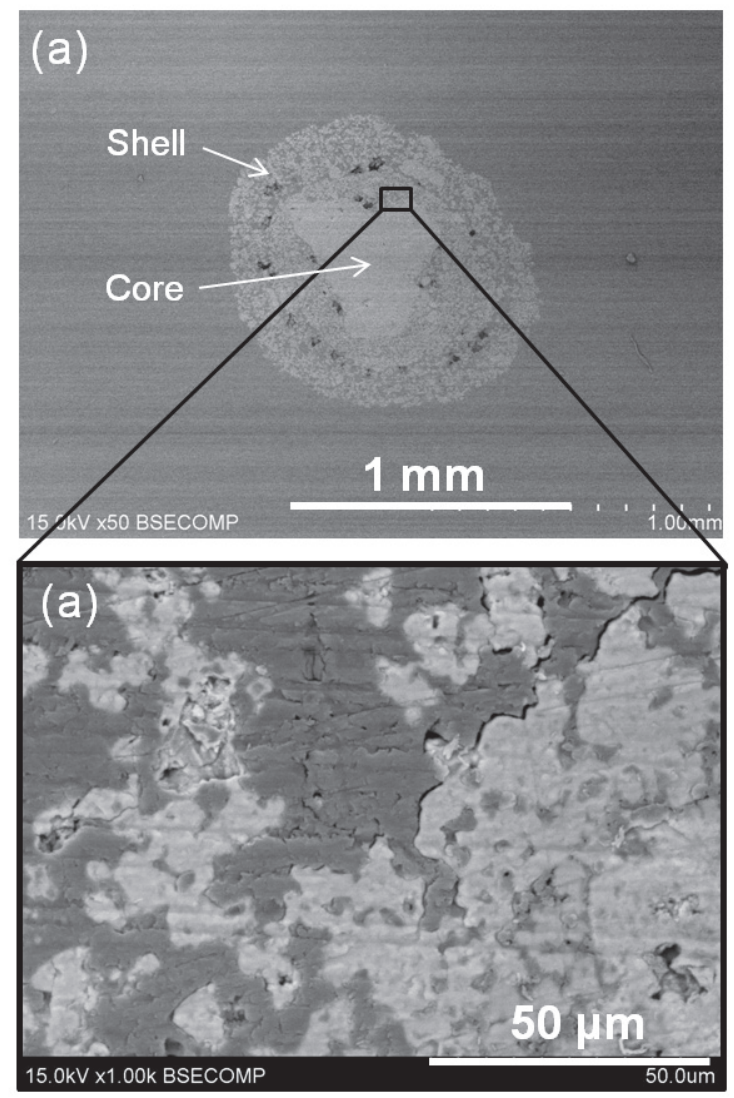

\section{$\mathrm{NaCl}$ core}

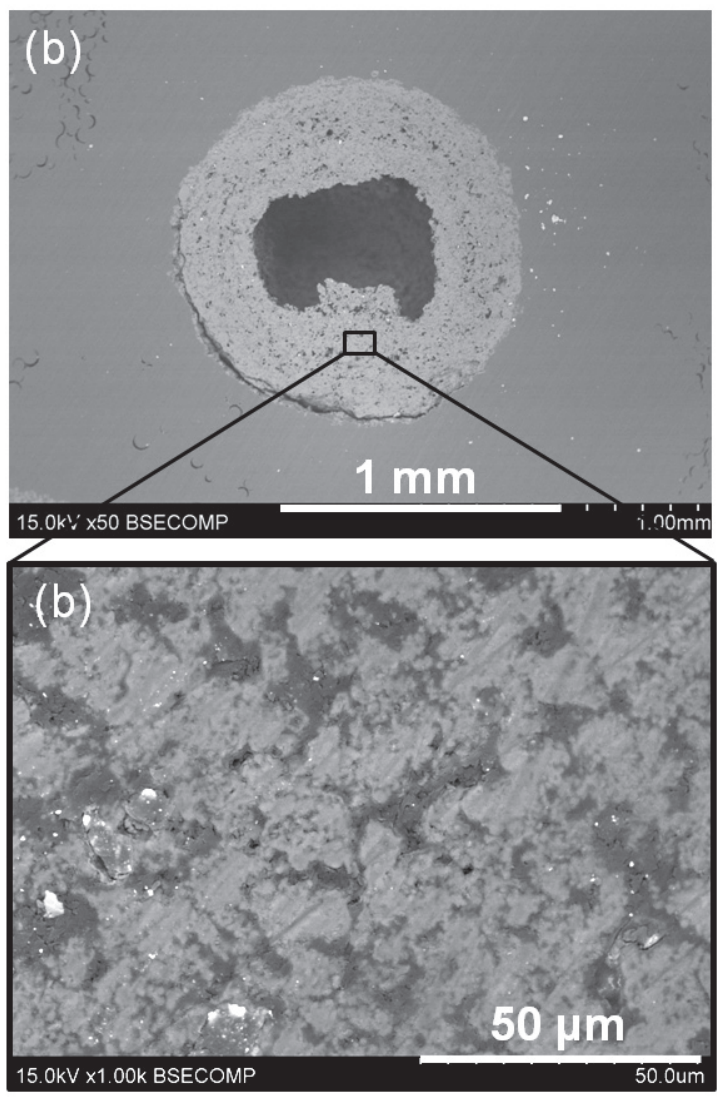

Fig. 9 Cross-sectional SEM images for $\mathrm{CO}_{3} \mathrm{Ap}$ microsphere prepared using calcite core (a) and $\mathrm{NaCl}$ core (b). 
particles as shown in Figs. 8(a) and 9(a). Apparent porosity of the hollow microsphere (approx. 65\%) was higher than that of the solid $\mathrm{CO}_{3} \mathrm{Ap}$ microsphere because of the hollow space in its center as indicated in Fig 9(b). It is well known that a hexagonal closest packing structure is built by piling up microspheres, the space occupied by these microspheres is $74 \%{ }^{27)}$, that is, the theoretical porosity of a hexagonal closest packing structure is $26 \%$. Therefore, total porosity of the solid $\mathrm{CO}_{3} \mathrm{Ap}$ microsphere is $(1 \times 0.74 \times 0.481+0.26) \times 100=61.6 \%$, and total porosity of the hollow microsphere is $(1 \times 0.74 \times 0.652+0.26) \times 100=74.3 \%$.

The mechanical strength was $1.4 \pm 0.4 \mathrm{~N}$ (solid) and $1.9 \pm 0.3$ (hollow), that is, the strength of the hollow microsphere was slightly higher than the solid microsphere. Huang et al. reported that a hollow HAp microsphere (500-800 $\mu \mathrm{m}$ in diameter) prepared by a glass conversion process showed a rupture of the sphere at compressive load of at least $350 \mathrm{mN}^{26)}$. However, it is impossible to compare the strength with the above value, because the particle size and thickness of the shell were different. The mechanical strength of 1.9 $\mathrm{N}$ in the present study is high enough for practical use as bone substitute. It was expected that the mechanical strength increased with wall thickness of hollow sphere, thus the solid microsphere should have a higher mechanical strength than the hollow one. However, the observed mechanical strength was unexpectedly higher in the hollow microsphere. This was probably due to a difference in microstructure of the $\mathrm{CO}_{3} \mathrm{Ap}$ phase between the solid microsphere and hollow one. The SEM photographs of the cross section of the microspheres revealed that $\mathrm{CO}_{3} \mathrm{Ap}$ crystals were more densely packed in the hollow microsphere as shown in Fig. 9. It is thought that $\mathrm{NaCl}$ used as the core of the hollow microsphere can be smoothed off more easily than the calcite core. Around core would make it possible to coagulate $\mathrm{Ca}(\mathrm{OH})_{2}$ powder more densely on the surface during granulation. Densely packed $\mathrm{CO}_{3} \mathrm{Ap}$ was formed by successive carbonation and phosphatization of $\mathrm{Ca}(\mathrm{OH})_{2}$ and this led to the high mechanical strength of the hollow microsphere. In the present study, though the core size was fixed around $300-500 \mu \mathrm{m}$, a solid or hollow $\mathrm{CO}_{3} \mathrm{Ap}$ microsphere with desired size and shell thickness could be fabricated by changing the core size and granulation conditions.

FT-IR spectra showed that $\mathrm{CO}_{3}{ }^{2-}$ ions were included in the $\mathrm{CO}_{3} \mathrm{Ap}$ microspheres. According to data from the literature, carbonate ions can be classified into A-type which gives peaks at $880,1,465$ and $1,545 \mathrm{~cm}^{-1}$, and B-type which shows different peaks at $872,1,412$ and 1,460 $\mathrm{cm}^{-1}{ }^{28,299}$. In this experiment, the carbon peaks observed for the specimens closely matched that of B-type carbonate. The absorption bands at 1,410 and $1,460 \mathrm{~cm}^{-1}$ belong to the vibration modes of $\mathrm{C}-\mathrm{O}$ of the $\mathrm{CO}_{3}{ }^{2-}$ group in B-type $\mathrm{CO}_{3} \mathrm{~A}_{\mathrm{P}}$ in which $\mathrm{PO}_{4}{ }^{3-}$ was partially substituted by $\mathrm{CO}_{3}{ }^{2-}$. These results showed that a $\mathrm{B}$-type $\mathrm{CO}_{3} \mathrm{Ap}$ solid microsphere could be obtained through dissolutionprecipitation reaction.

\section{CONCLUSION}

The present study demonstrated that solid and hollow $\mathrm{CO}_{3} \mathrm{Ap}$ microsphere could be easily prepared based on a four-stage method: (1) preparation of the core (calcite (solid), $\mathrm{NaCl}$ (hollow)), (2) granulation with $\mathrm{Ca}(\mathrm{OH})_{2}$ using the core, (3) conversion of the $\mathrm{Ca}(\mathrm{OH})_{2}$ to calcite by carbonation, and (4) conversion of the calcite to $\mathrm{CO}_{3} \mathrm{Ap}$ by phosphatization. It was expected that the fabricated solid and hollow $\mathrm{CO}_{3} \mathrm{Ap}$ microspheres can be used for a constituent of resorbable bone substitute with a 3-dimensional porous structure.

\section{REFERENCES}

1) Kay MI, Young RA, Posner AS. Crystal structure of hydroxyapatite. Nature 1964; 204: 1050-1502.

2) LeGeros RZ. Apatites in biological systems. Cryst Growt Character. 1981; 4: 1-45.

3) LeGeros RZ. Calcium phosphates in oral biology and medicine. Monographs in Oral Sci 1991; 15: 1-201.

4) LeGeros RZ, Ming S. Chemical-stability of carbonatecontaining and fluoride-containing apatites. Caries Res 1983; 17: 419-429.

5) LeGeros RZ. Properties of osteoconductive biomaterials. Calcium phosphates. Clin Orthop 2002; 395: 81-98.

6) Chang BS, Lee CK, Hong KS, Youn HS, Ryu HS, Chung SS, Park KW. Osteoconduction at porous hydroxyapatite with various pore configurations. Biomaterials 2000; 21: 12911298.

7) WakaeH,Takeuchi A, Udoh K, Matsuya S, Munar ML, LeGeros RZ, Nakasima A, Ishikawa K. Fabrication of macroporous carbonate apatite foam by hydrothermal conversion of alphatricalcium phosphate in carbonate solutions. J Biomed Mater Res A 2008; 87: 957-963.

8) Karashima S, Takeuchi A, Matsuya S, Udoh K, Koyano K, Ishikawa K. Fabrication of low-crystallinity hydroxyapatite foam based on the setting reaction of $\alpha$-tricalcium phosphate foam. J Biomed Mater Res A 2009; 88: 628-633.

9) Oonishi H, Hench LL, Wilson J, Sugihara F, Tsuji E, Kushitani S, Iwaki H. Comparative bone growth behavior in granules of bioceramic materials of various sizes. J Biomed Mater Res 1999; 44: 31-43.

10) Kasai T, Ishikawa K, Suzuki K, Yatani H. Initial evaluation of ceramic foam as a reconstructive material for bone defects. Dent Mater J 2000; 19: 381-388.

11) Karageorgiou V, Kaplan D. Porosity of $3 \mathrm{D}$ biomaterial scaffolds and osteogenesis. Biomaterials 2005; 26: 54745491.

12) Hutmacher DW, Garcia AJ. Scaffold-based bone engineering by using genetically modified cells. Gene 2005; 347: 1-10.

13) Munar ML, Udoh K, Ishikawa K, Matsuya S, Nakagawa M. Effects of sintering temperature over $1300^{\circ} \mathrm{C}$ on the physical and compositional properties of porous hydroxyapatite foam. Dent Mater J 2006; 25: 51-58.

14) Kandori K, Yasukawa A, Ishikawa T. Preparation and characterization of spherical calcium hydroxyapatite. Chem Mater 1995; 7: 26-32.

15) Aizawa M, Terada T, Howell FS, Itatani K. Preaparation of spherical apataite particle by the homogeneous precipitation method in the presence of magnesium ions and their ionexchange properties. Mater Res Bull 1999; 34: 1215-1225.

16) Kleinebudde P. Roll compaction/dry granulation: pharmaceutical application. Eur J Pharm Biopharm 2004; 58: 317-326.

17) Maejima T, Ohsawa T, Kobayashi M, Noda K. Factors effecting spherical granulation of drugs by tumbling granulation 
method. Chem Pharm Bull 1992; 40: 488-492.

18) Watano S, Yeh N, Miyanami K. Drying of granules in agitation fluidized bed. J Chem Eng Jpn 1998; 31: 908-913.

19) Murakami H, Yoneyama T, Nakajima K, Kobayashi M. Correlation between loose density and compactibility of granules prepared by various granulation methods. Int $\mathrm{J}$ Pharm 2001; 216: 159-164.

20) Ioku K, Kawachi G, Sasaki S, Fujimori H, Goto S. Hydrothermal preparation of tailored hydroxyapatite. J Mater Sci 2006; 41: 1341-1344.

21) Yao A, Ai F, Liu X, Wang D, Huang W, Xu W. Preparation of hollow hydroxyapatite microspheres by the conversion of borate glass at near room temperature. Mater Res Bull 2010; 45: 25-28.

22) Fu H, Rahaman MN, Day DE. Effect of process variables on the microstructure of hollow hydroxyapatite microspheres prepared by a glass conversion method. J Am Ceram Soc 2010; 93: 3116-3123.

23) Lin X, Matsuya S, Nakagawa M, Terada Y, Ishikawa K. Effect of molding pressure on fabrication of low-crystalline calcite block. J Mate Sci: Mater Med 2007; 19: 479-484.

24) Lin X, Matsuya S, Nakagawa M, Udoh K, Terada Y, Ishikawa
K. Fabrication of calcium carbonate monolith by carbonization of calcium hydroxide compact. Arch BioCeram Res, 2003; 3: 83-88.

25) Ishikawa K, Matsuya S, Lin X, Zhang L, Yuasa T, Miyamoto Y. Fabrication of low crystalline B-type carbonate apatite block from low crystalline calcite block. J Ceram Soc Jpn 2010; 118: 341-344.

26) Huang W, Rahaman MN, Day DE, Miller BA. Strength of hollow hydroxyapatite microspheres prepared by a glass conversion process. J Mater Sci: Mater Med 2009; 20: 123129.

27) William DC. Fundamentals of materials science and engineering. New York: John Wiley \& Sons, Inc; 2001. p. 288289.

28) Monma H, Takahashi T. Preparation and thermal changes of carbonate-containing apatite. Gypsum and Lime 1987; 210: 287-291.

29) Lafon JP, Champion E, Bernache-Assollant D. Processing of AB-type carbonated hydroxyapatite $\mathrm{Ca}_{10-\mathrm{x}}\left(\mathrm{PO}_{4}\right)_{(6-\mathrm{x})}\left(\mathrm{CO}_{3}\right)_{(\mathrm{x})}$ $(\mathrm{OH})_{(2-x-2 y)}\left(\mathrm{CO}_{3}\right)_{(\mathrm{y})}$ ceramics with controlled composition. J Eur Ceram Soc 2008; 28: 139-147. 